\title{
National Character Building Through Manners Education Based on Regional Culture of North Sumatra
}

\author{
Efendi Napitupulu., Keysar Panjaitan., Hamonangan Tambunan
}

University of Medan, Indonesia

\begin{abstract}
National character building role is to enhance positive behavior for learners to interact with their environment. Manners education should be able to establish the identity of learners through the development of multi-faceted potential advantages of nations and multidimensional as it includes the dimensions of nationality and regional culture is currently in the process of finding regional cultural attributes that can be developed into manners learning model based on regional culture of North Sumatra. How to settle character and moral matters of learners as a form of mental revolution is very important to develop. This research approach in the early stages of research developmentwith reference assessment and and field study design with the culture and customs cases. Data collection techniques used include: observation, interviews, and documentation. Data were analyzed using data reduction, data presentation, data verification. The field findings show that regional culture attributes relevant to the national character building.
\end{abstract}

Keywords- National character building, Manners education, Regional culture.

\section{PRELIMINARY}

As stated in the National Long Term Development Plan year 2005 - 2025 (Law of the Republic of Indonesia Number 17 year 2007), namely the establishment of a national character that is strong, competitive, noble, and morality based on Pancasila, which is characterized by the nature and human behavior and Indonesia's diverse society, faith and fear of Almighty God, virtuous, tolerant, mutual cooperation, patriotic spirit, developing dynamically, and science technology-oriented.

Real conditions that occur at this time uncertainty identity and national character that boils down to (1) disorientation and not internalized yet values of Pancasila as the philosophy and ideology of the nation, (2) the limitations of the policy tools integrated in realizing the values of the essence of Pancasila, (3) shifting the value of ethics in the life of the nation and state, (4) the waning awareness of the cultural values of the nation, (5) the threat of national disintegration, and (6) the weakening of the nation's independence.

National character building has a very broad urgency and multidimensional. Very spacious as it relates to the development of multi-faceted potential advantages of nations and multidimensional as it includes the dimensions of nationality, is currently in the process of finding regional cultural attributes that can be developed into a manners learning model based on regional culture of North Sumatra. In this respect it is also mentioned that (1) the character is very essential in the nation and the state, the loss of character will lead to the loss of the next generation; (2) the character serves as - rudder and strength so that this nation does not vacillate; (3) the character does not come by itself, but must be built and set up to be a dignified nation. Furthermore, the national character building will be narrowed to the three major level, namely (1) to foster and strengthen national identity, (2) to maintain the integrity of the Unitary Republic of Indonesia (NKRI), and (3) to form the human and the Indonesia society who have a certain noble and dignified nation.

Thus the study of character building becomes important to find models of effective and efficient learning integrated with the existing character education in regional culture.

Character and moral problems of learners, including: (1) capability not optimal yet and readiness of human resources in the school environment in performing the manners learning process based on regional culture; (2) school less than optimal to establish a pattern of behavior of learners in following the process and implementation of mental revolution in the school; (3) understanding and experience of teachers are still lack in choosing manners learning model that effective and efficient in shaping the identity of learners; (5) the manners learning model is still lack based on regional culture in character building of learners as nation. Based on these things interesting for conscientious manners learning model based regional culture in North Sumatra. The outcomes of this research represent an early stage by reviewing how the relevance of the regional culture attributes of North Sumatra in the 
national character building.

\section{DISCUSSION}

\section{National Character Building}

National character is the quality of the national typical collective behavior well-reflected in the awareness, understanding, taste, intention, and behavior of the state and nation as an outcome of a thought, though the heart, though the taste and intention, as well as the sports person or group of people. Indonesian national character will determine the collective behavior of the typical Indonesian nation well reflected in the awareness, understanding, taste, intention, and behavior of nation and state of Indonesia based on Pancasila values, UUD 1945 norms, diversity under the principle of Bhinneka Tunggal Ika (unity in diversity), and commitment to the NKRI.

National Character Building is a collective effort-systemic a nation-state to realize the life of the nation and state in accordance with the basic and ideologies, constitutions, state policy, and the potential of the collective in the context of national, regional, and global civilized to form the nation's tough, competitive, noble, moral, tolerant, mutual cooperation, patriotic, dynamic, culture, and science technology-oriented based on Pancasila and animated by faith and piety to the One Almighty God. National character building performed coherently through a process of socialization, education and learning, empowerment, acculturation, and the cooperation of all components of the nation and the state.

Individual character inspired by principles of Pancasila on each part, it can be stated as follows: 1) the character that comes from though the heart, including faith and piety, honest, trustworthy, fair, orderly, law-abiding, responsible, empathize, dare to take risks, unyielding, self-sacrificing and patriotic spirit; 2) the character that comes from thought including, intelligent, critical, creative, innovative, curious, productive, science and technology-oriented, and reflective; 3) The characters that comes from sports / kinesthetic including clean, and healthy, sportive, strong, reliable, resilient, friendly, cooperative, determinative, competitive, cheerful, and persistent; 4) The characters that comes from though the taste and intention including humanitarian, mutual respect, mutual cooperation, togetherness, friendly, respectful, tolerant, nationalist, caring, cosmopolitan (worldwide), give priority to the public interest, patriotism (patriotic), proudly use Indonesia language and product, dynamic, work hard, and work ethic.

There are eighteen education indicators of national character: Religious, Honest, Tolerance, Discipline, Work Hard, Creative, Independent, Democratic, Curiosity, Excitement Nationality, Homeland Love, Rewarding Achievement, Friendly / Communicative, Love Peace,
Joy of Reading, Caring environmental, Social Care, Responsibility.

In the implementation of Indonesian national character education does not stand alone but integration with existing lessons by incorporating the values of the character and culture of Indonesia. National character education can be conducted by noble moral values habituation to learners and familiarize them with habits in accordance with national character. Here grains indicator of national character that can be used as matter for implementing of nationalcharacter education:

National Character Building Potential functions to forming and developing the potential of a human being or an Indonesian citizen in order to good thoughts, goodhearted, and good behaved in accordance with the Pancasila philosophy of life.

National character building functions to improve and strengthen the role of the family, educational units, communities, and governments to participate and responsible for developing the potential of citizens and national building towards a developed nation, independent, and prosperous.

National character building functions to break his own national culture and screening cultures of other nations that do not conform with the values of the culture and character of the nation's dignity.

National character building aims to foster and develop the character of citizens so as to realize the community's belief in the one and only God, Just and civilised humanity, spirited The unity of Indonesia, spirited Democracy guided by the inner wisdom in the unanimity arising out of deliberations amongst representatives, and Social justice for all of the people of Indonesia.

These three functions conducted by (1) Adoption of Pancasila as the philosophy and ideology of the state, (2) Adoption of values and constitutional norms UUD 45, (3) Strengthening national commitment of the Republic of Indonesia (NKRI), (4) Strengthening the values of diversity appropriate the conception of Bhinneka Tunggal Ika (Unity in Diversity), and (5) strengthening the excellence and competitiveness of the nation to the sustainability of society, nation and state of Indonesia in the global context.

Character building can be conducted in the scope of family, the scope of the educational unit, the scope of government, the scope of the civil society and the scope of political public. Education unit is a vehicle for the promotion and development of character made using (a) an integrated approach in all subjects, (b) culture building of education unit, (c) the implementation of curricular and extracurricular, and (d) behaviorhabituation in life at education unitsenvironmental. Character building through education unit carried out starting from early childhood 
education to higher education.

\section{Manners Learning Model}

According to Gustafson (1984), which emphasizes the practical function models is means to facilitate communication, or a regular user (algorithm) that prescriptive for making decision, or planning guidelines for management activities. Further Nadler (1988) explains that a good model is a model which can help the user to understand what is fundamentally a thorough process. Basic good model is the linkage of several theories. It is said there are several benefits of the model to the user, including: (1) explain some aspects of behavior and human interaction, (2) integrate what is known through observation and research, (3) simplify the complex humanitarian, (4) the guidelines for the conduct activity. Relation to learning model implementation function to directing implementer activity manners learning programs in national character building to design implementation systems that are used in accordance with the scenario of learning that was developed as a guide in the implementation process of manners learning based on culture that effective and efficient. As an example of the use of models in learning, Joyce (1992) describes the learning model is a plan or a pattern which is used as a guide in the classroom learning or learning in tutorials and to determine the tools of learning and guide us in designing learning to help learners so that the learning objectives achieved.

In this research, the model development is defined as a process of systematically in the design, construction, use, management and evaluation system of the implementation of the education policy. This process is often expressed in the form of prescriptive models.

\section{Cultural Analysis}

The analysis used by Iceberg Theory is to determine the level of understanding and necessary action in anticipation. Iceberg Theory is basically offers analysis techniques to map the presence of symptoms of a problem on several levels, namely:

a. Event, which describes culture indications that can be observed in concrete or can be directly perceived by the public. This indication is followed by action step reactively by the relevant authorities with the problem.

b. Pattern, which describes culture indication be the original cause of their symptoms, abstract and has a recurring pattern of events based on time, conditions or the originator of the problem. This indication is followed by action step responsively by the relevant authorities.

c. Structure, which describes culture indication that the cause is deeper than the symptoms, structured or organized in certain ways. This indication is followed by action step generatively by the relevant authorities that because it is common and can be treated equally relatively or do a logical grouping by categories.

d. Mental models, which describe the character values that are formed in the public perception of an event that can be observed, has a specific pattern, and can be structured in a certain way. Mental models are deepest indicative that can be obtained from this analysis technique. Indications of certain mental models will produce fundamental actionstep by the relevant authorities.

\section{RESEARCH METHODS}

This research uses a research development approach. Made directly with descriptive data collection that are processing and data analysis is inductive (Bogdan and Biklen, 1982). Research development conducted through Research and Development (Research and Development/ $\mathrm{R}$ \& D) modified. According to the approach model research and development, the implementation of this research follow the steps, a preliminary survey, planning models, test models, validationmodel and dissemination. The initial steps of the research conducted to find a character attribute model based regional culture in North Sumatra, the locus of research on cultural analysis Batak Toba, Karo, Simalungun and Malay. To get the data conducted review of reference and surveys of cultural to the implementation of customs (certain cases only).

\section{RESEARCH OUTCOMES}

\section{Cultural Analysis Batak Toba}

Batak Toba people known to have a good educational system. It reads from a sort of proverb, "Sian jabu baru tu alaman, sian alaman tu balian" (From the home to yard, from the yard to the fields or jobs). But, it was then. An advantage Batak people who appear to have been lost. Educational paradigm in Batak Toba has changed. And, the advantage once enjoyed Batak Toba was not separated from Ludwig Ingwer Nommensen services (1834-1918). One way of life Batak Toba which reads "Anakhon Hi Do Hamoraon Di Ahu" has strengthened the motivation of people to educate their children as high as possible. In the context of the philosophy of Batak Toba, hamoraon is a wealth of material, gabe, mamora, sangap. This means that there are children, there is a treasure, will get a reputable position.

As a society, Batak Toba people recognize their social life can not be separated from the culture possessed. The concept of this society culture in science has been discussed widely in terms of disciplines of sociology and anthropology. The description of a number of books that explain and describe the Batak Toba culture, it was found 
that the same definitions of culture Batak Toba which has two dimensions, form and content. The same thing, expressed Koentjaraningrat about culture as the expression of ideas, concept and human action in meeting the needs of everyday life, which is obtained through a process of learning and teaching. The linkage Batak pedigree between mythology with a clan status of each of the Batak.

Batak Toba culture is an inherited form of the idea of owners community to make a behavior towards cultural values. Batak Toba society concept of human life, is that life is always related to and governed by traditional values. Tradition is part of the obligation that must be adhered to and implemented. In practice, the implementation of the Batak Toba, reality on the ground shows that there are four (4) categorical tradition that has been done. First, the Batak Toba community has its own customs relations system. Shows, each community has a traditional typology respectively. The rural communities treatment of tradition towards more intensive and glue, the Batak society who live in cities relatively more individualistic addressing traditional Batak. This behavior appears as a result of environmental influences that shape the mindset besides the technology elements that influence. Second, the tradition was believed to be the norms that govern Batak Toba human relationships, affected by the rules and norms that have been prevailing in the society. Legislations and religious laws which regulate many normative community life in itemized and detail, reduce customary role in regulating social norms and its social life. As well as the rule of law and religious law that have been entrenched, also often seen and considered as part of the traditional Batak Toba itself. Third, the pattern of human relationships in Batak Toba society change constantly, so the implementation of customary also changed as needed without seeing the space and time. Fourth, the views and the value assigned to the tradition is also changing, as a result of the influence of technology in dissemination of information. It is reflected in customary practices conducted by community supporters.

\section{Cultural Analysis Karo}

Batak Karo tribe is one of tribes who inhabited the Highlands Karo, North Sumatra, Indonesia. This tribe is one of the largest tribes in North Sumatra. Because the majority tribe in the city of Medan, karo language became mandatory language in Medan city. This tribal name as one name in one of the district where they lived (Karo Highlands) Tanah Karo. This tribe has its own language called Karo Language or Karo Proficient. Karo tribal clothes dominated by the red color as well as black and filled with gold jewelry.
One of the supporting variables and driving customs in Karo society is daliken si telu. The dominant values contained in daliken si telu this is the value of mutual cooperation and kinship. Etymologically daliken si telu means "three furnaces". daliken = furnace stone, $s i=$ which, $t e l u=$ three. This reality points to the function of the furnace stone as a place to light a fire (to cook). But there is also interpret it rakut si telu (bond three). But there is also perceive it as sangkep nggeluh (completeness of life). This concept is not only owned by the Batak Karo, but also owned by another Batak with a different name. In the Batak Toba and Mandailing known dalihan na tolu term, in the NTT known lika Telo (Wirateja, 1985).

Daliken si telu or rakut si telu or sangkep nggeluh elements is kalimbubu (Karo) hula-hula (Toba) mora (Mandailaing and Angkola) todong (Simalungun), sembuyak/ senina (Karo) dongan sabutuha (Toba) Kahanggi (Mandailing and Angkola) Sanina (Simalungun), and anakberu (Karo) boru (Toba, Mandailing and Angkola) anak boru (Simalungun).

So daliken si telu is the foundation of the kinship system and become the foundation for all activities, particularly activities related to the implementation of the customs and the interaction among fellow Karo community. Daliken si telu is powered by three actors known as kalimbubu, sembuyak/ senina, and anakberu). Or in other languages, daliken si telu is a social-cultural network of mutual cooperation and togetherness are contained in Karo society.

One principle of Karolife society is as written in Surat Ukat (spoon letters is writing a letter written on rice scoop that made of piece of bamboo). The written word in the scoop er-endi enta(give and ask), the nature of this erendi enta, unrequited; not only give or ask for it, but the implementation of give and ask to be in place. When someone gives something to us, then we must also reciprocate by giving something to the personalso. About the value of the goods we gave it not worth to a given person, it was not questioned.

At Karo society, the implementation of mutual cooperation has always been and remains the basis of kinship in sangkep sitelu(Kalimbubu, Senina/ Sembuyak and Anakberu). Implementation of mutual cooperation include field at funerals, build a house, overcome suffering caused by disasters, the implementation of a marriage party. The implementation of mutual cooperationalways associated with traditional activities, or part of a tradition implementation.

The types of mutual cooperation in Karo society is

a. Urup-urup assisted in abuzz regardless of with or without relatives.

b. Sampati (assisted), usually assisted relatives, could be 
with involve anakberu, kalimbubu, sembuyak ego.

c. Serayan, is one of the forms of mutual cooperation that the perpetrators are youth. Mutual cooperation is done in traditional events, such as weddings, burial of the dead. Forms of mutual aid are the youth help each other solving work related to consumption. This work was conducted without expecting material rewards

d. Aron. Aron is a mutual cooperation group take turns working in the farm / field, located in a village, whose members are all composed of women who have grown up and able to cooperate with each other. Aron was led by a lady called nande aron (Mrs. Aron), and escorted by a man who is called Bapa Aron.Bapa Aron function is to keep the members of the aron from bad guys ignorance. The number of the working group of eleven people.

\section{Cultural Analysis Simalungun}

Simalungun tribe is one of the native tribes of North Sumatra, Indonesia. Simalungun in Simalungun language has a basic word "lungun" which has the meaning "silence". The name was given by outsiders because the population is very sparse and the place is very far apart from each other. Batak Toba people call it "Si Balungu" from the legend of a ghost that cause epidemics in the region, whereas the Karo call the Eastern Batak for housed in the east of them.

Regarding the honesty of the Simalungun guided by the philosophy of life, they are Habonaron do Bona, Hajungkaton do Sapata "which means everything must stem from the right. People who do not consistently uphold the philosophy is believed to get the things that are not good. This philosophy also affects the mindset of Simalungun people that very cautious in making decisions. A decision is then taken after deliberation in mind, and once he decided that he rarely appealing that decision.

As in Simalungun phrase, "Parlobei $i$ dilat bibir ase marsahap, bijak mosor pinggol asal ulang mosor hata". This expression indicates that the Simalungun person is not human reckless typical or hasty in taking action and adopting a policy and decisions, all should be considered carefully and a decision it is fixed, means it will never change again.

The doctrine of God, Human and Nature. According to the trust Habonaron Do Bona, the Almighty God is the beginning of everything that exists. Almighty God is referred to as Naibata. Naibata is one (sada) and omnipotent (Namar Kuasal Namar Huasa). Because Naibata is the beginning of everything that exists, then the world and all its contents are His creation. As the Creator, Naibata also become counselors, custodians, and savior for all his creatures. Supporting community trust
Habonaron Do Bona honoring ancestors called Simagot, Begu Jabu, Tua-tua or Batara Guru. According Habonaron Do Bona, ancestors are the link to pass the command of Almighty God to certain people that took place single-mindedly towards his favorite offspring.

In connection with the matter, the power of God is unlimited and God may bestow His most power to the saints were clean birth and his inner, to the ancestral spirits and the sacreds. Because also of His power, so many names for Almighty God, like: Namar Huasa (The Almighty God), Namam botoh or Ne Pentar (The Omniscient God), Pemolong (The Merciful God), Pangarak-arak (The Guide God), Bona Habonaron (God Source of Truth) and many other names.

\section{Cultural Analysis Melayu}

Malay traditions and cultures in essence is the artery, the main pillar or ultimate material components for the formation of national culture of Indonesia. The Malay culture was the main actor who unite into one unified Indonesian culture as far days before Indonesia itself is accepted as the name for the community of life on the archipelago which is then formed into one of the Republic of Indonesia. Since the days of the Srivijaya kingdom Malay language has been widely accepted as the 'lingua franca' of society archipelago from Sabang to Merauke, from Minangas to the Rote island. Inscription heritage sites Sriwijaya kingdom as the first biggest kingdom to unite the archipelago, are found in Malay.

Customs ceremony at the Palace of the sultan in general are as follows: Welcoming a newborn child; Down to the river, unshaven and swinging; Circumcision/ Rasul Circumcision; Coronation of Crown Prince (Tengku Besar); Marriage/ wedding; Coronation of King; and the king died.

Malay tradition is "Traditionary guided Syarak, Syarak guided kitabullah". So that Malay people are ethnic culturally (culture), not necessarily in genealogy (equation consanguinity); Rests to the One as the saying goes: Depending on which one, hold on to that one, good luck to live the perfect life, intelligent life faithful dead, poor living wretched lives, lives not know halal haram; very concerned to the rule of law (law enforcement) for security, neatness, and prosperity of society. As disclosed adage: Indigenous above the growth, above the consensus made, Let the dead children than indigenous dead, dead children uproar compatriot, countryman uproar custom die; prioritizes mind and language. It shows good manners and high civilization, as disclosed adage: The proposal indicates the origin, the language showed the nation, obedient to the advice, faithful to the oath, Dead at appointment, destitute in the minds, lives in manners, dead in the mind, knows the mind there is debt, know life 
is no burden; prioritize education and science. This is reflected in the proverb: Seeking knowledge do not hesitate, true science, the science of virtue, the contents of this book already mentioned. All deeds with knowledge, then virtue must meet, do not arbitrarily mixed together, eventually you fall shade. Science is a big boondoggle, distinguish truth with its falsehood, knowing many people the truth or falsity, so judged with fairness, opened the provision of science, provisions saving faith; cultural importance. This was revealed in the adage: Speaking is not rough, dressed in revealing, abstinence distanced ban and sin. Let die than to bear the shame of his or her family, because it can drop the dignity of the offspring, otherwise harshly humiliate others; deliberation and consensus prioritizes as the joint social life. This

\section{Preliminary Research Outcome}

1. Preliminary Analysis Manners Learning Model Based on Culture

\begin{tabular}{|c|c|}
\hline INDICAT & \\
\hline $\begin{array}{l}\text { Event : } \\
\text { Implementation of manners learning system } \\
\text { less effective and efficient }\end{array}$ & $\begin{array}{l}\text { manners learning modeibased on culture } \\
\text { nt. }\end{array}$ \\
\hline $\begin{array}{l}\text { contradiction between manners } \\
\text { model with the national character }\end{array}$ & : \\
\hline $\begin{array}{l}\text { Structure : } \\
\text { - Errors in implementing the manners learning } \\
\text { process } \\
\text { - Consistency implementation manners } \\
\text { learning model do not have a standardized } \\
\text { guidelines } \\
\text { - Mechanisms of manners learning do not run } \\
\text { effectively and efficiently }\end{array}$ & $\begin{array}{l}\text { Generative : } \\
\text { - The scenario construction and implementation mechanisms of } \\
\text { manners learning programs based on culture in the classroom. } \\
\text { - The operational steps preparation of manners learning based on } \\
\text { culture are arranged together in consistent and sustainable. } \\
\text { - Mechanismdevelopment manners learning process based on } \\
\text { culture that effectively and efficiently. }\end{array}$ \\
\hline $\begin{array}{l}\text { Mental Models : } \\
\text { - Learner character have not yet formed } \\
\text { - Improved and awareness of ethical and moral } \\
\text { learners hampered } \\
\text { - The manners learning system has not yet } \\
\text { formed a positive behavior for learners } \\
\text { - Regional culture are not considered as a } \\
\text { potential component for character building } \\
\text { of learners }\end{array}$ & $\begin{array}{l}\text { Fundamental : } \\
\text { - Determine the character attributes of the nation } \\
\text { - Determine the competencies to be achieved by the learners } \\
\text { through the manners learning process based on culture in } \\
\text { schools } \\
\text { - Improve the harmonization manners learning process based on } \\
\text { culture with subject matter learning. } \\
\text { - Arrange a learning scheme through the regional culture } \\
\text { component of potential which are integrated with the operational } \\
\text { guidelines for effective and efficient learning. }\end{array}$ \\
\hline
\end{tabular}

\section{Agenda Setting Analysis}

\begin{tabular}{|l|l|}
\hline Private Problem & $\begin{array}{l}\text { Learners are difficult to obtain patterns of manners learning to build the } \\
\text { nation's character }\end{array}$ \\
\hline Public Problem & $\begin{array}{l}\text { School has not received the recognition and shifting values of the } \\
\text { community as a place that is believed to be capable of forming a national } \\
\text { character more appropriate. }\end{array}$ \\
\hline
\end{tabular}

condition is seen in marriage, death, festivity, build houses, open fields/ business, within the Government and others; Malays are friendly and open to guests. Hospitality and openness of the Malays against all immigrants (guest) is mainly Muslim, rooted to the Malay King Political maritime to enliven the city with the merchants, as in the proverb: When sharpening selodang reed, Prepare stick exhaust its miang, When you pick up people distant, Prepare rice with its serving; Malays fight if pressed, as in the saying: if it were intoxicated nut, rather than to the mouth so that to heart, when it entered into the arena, rather than the ebb willingly was dead, eagle one two grasshoppers, would trunked wood straw, missing one two fairly, not Malays lost on the earth. 


\begin{tabular}{|l|l|}
\hline Issues & $\begin{array}{l}\text { - Deviant behavior from learners } \\
\text { - The manners learning system not well ordered } \\
\text { - Lack of synchronization between the learning objectives related to the } \\
\text { national character building and manners of the regional culture. }\end{array}$ \\
\hline Sistemic Agenda & $\begin{array}{l}\text { - Schools began to lose direction in the national character building } \\
\text { - Implementation manners learning system are still dependent on the } \\
\text { principal's instructions, yet varied. } \\
\text { - The high dependence on the teachers' learning patterns that already exist } \\
\text { and are reluctant to change the manners learning model are more active } \\
\text { and creative. } \\
\text { - The weak synchronization manners learning program with subject-matter } \\
\text { based on culture. }\end{array}$ \\
\hline Institutional Agenda & $\begin{array}{l}\text { Input for the development manners learning model based on regional } \\
\text { culture from government agencies, the public, the media, etc. } \\
\text { - The initial design manners learning model based on regional culture that } \\
\text { includes learning plan, execution, control and evaluation of the } \\
\text { implementation learning system and institutional. }\end{array}$ \\
\hline
\end{tabular}

\section{Outcome Analysis of National Character Building Attribute Based on Regional Culture of North Sumatra}

For the initial draft development of manners learning model based on regional culture conducted by problem input that will be resolved through culturally relevant analysis as an alternative offered into manners learning competencies. The outcome of the analysis of national character building attributes that are relevant to the regional culture attributes of North Sumatra described as the table below:

\begin{tabular}{|c|c|c|c|}
\hline Input & $\begin{array}{l}\text { Analysis: Regional Cultural } \\
\text { Attributes relevant }\end{array}$ & Draft Model & Implementation \\
\hline $\begin{array}{l}\text { National Character } \\
\text { Building: Religious, } \\
\text { Honest, Tolerance, } \\
\text { Discipline, Work Hard, } \\
\text { Creative, Independent, } \\
\text { Democratic, Curiosity, } \\
\text { Excitement Nationality, } \\
\text { Homeland Love, } \\
\text { Rewarding Achievement, } \\
\text { Friendly / Communicative, } \\
\text { Love Peace, Joy of } \\
\text { Reading, Environmental } \\
\text { Care, Social Care, } \\
\text { Responsible. }\end{array}$ & $\begin{array}{l}\text { Manners Learning: Belief in } \\
\text { the one and only God and the } \\
\text { Spirit of the ancestors, Values } \\
\text { and Typology Customs, } \\
\text { Cohesiveness / Kinship } \\
\text { Genealogy / Patterns of } \\
\text { relationship Between } \\
\text { Humans, Regional } \\
\text { Languages, Variety Clothing } \\
\text { Traditional, Arts and Dance } \\
\text { Area, Alphabet / Writing, } \\
\text { poems / proverbs, The } \\
\text { mindset / philosophy of life } \\
\text { tribal area }\end{array}$ & $\begin{array}{l}\text { Manners learning } \\
\text { model design based } \\
\text { on culture set to be } \\
\text { learning model that } \\
\text { serves as the main } \\
\text { reference for all the } \\
\text { manners learning } \\
\text { activities. }\end{array}$ & $\begin{array}{l}\text { Implementation of } \\
\text { manners learning model } \\
\text { based on regional culture } \\
\text { that effectively and } \\
\text { efficiently. }\end{array}$ \\
\hline
\end{tabular}

\section{CONCLUSION}

1. Readiness of teachers in implementing the mannerslearning is likely to have been prepared; the teacher presents a lesson before the first draw up lesson plans (RPP) well enough; the subject matter presented does not have any teaching materials; learning strategies are used less good; active students in learning quite well; evaluations or tests are given quite good in the sense relevant to the material presented, and the problems encountered in the implementation of leraning is lack of availability of teaching materials and textbooks, it is difficult to find a theme and share learning time, the task of the teacher is too many, and the lack of instructional media.

2. The learning model used by teachers are less effective, efficient and diversified to achieve the learning objectives.

3. In teaching teachers already greeted the learners when entering the classroom and motivating then presents the topics immediately that will be presented, without explaining the learning objectives.; already using good communication in a variety of voice, body movement, hold eye contact, focus and change the position in the class was good. But less systematic description of subject matter presented. Teacher in presenting the 
subject matter only on the substance of the matter and give less opportunity for learners to express their opinions, but there is also a small portion has been linked with the daily life of learners; The learning method used by teachers generally still dominant in the form of lectures, and question and answer. But there is also a small part of teachers using a variety of teaching methods such as lectures, discussion, practice, play and small group discussions. Teacher in presenting the lesson is very less use of instructional media. However, most teachers have used textbooks, other Indonesian reference books as a learning resource, and some students have had the recommended teacher handbook. Teachers do not use subject matter teaching to support the achievement of learning goals; In the closing lesson fraction teacher gives evaluation, feedback and revisiting subject matter (give summary) has been presented as well as more likely to give homework to learners.

4. There are 18 aspects of characters that can be explained as the result of several processes, including: Religious; Honest.; Tolerance.; Discipline; Work Hard; Creative.; Independently; Democratic; Curiosity; National spirit; Homeland Love; Rewarding Achievement; Friends/ Communicative; Love peace.; Joy of reading; Environmental care; Social care ; And Responsibility.

5. National character building can be conducted through manners learning based on regional culture of North Sumatra.

6. Regional culture attributes that can be used as learning subject, including: Belief in the one and only God and the ancestral spirits, Values and Customs Typology, Cohesiveness/ Kinship Genealogy/ Patterns of relationship Between People, Language and Regional Literacy, Traditional Clothing, Art and Regional Dances, Poem/ Proverb, Tales and Folklore, Mindset/ philosophy tribes living area of North Sumatra.

\section{REFERENCES}

[1] Agustono, B, et.al. 2012. Sejarah Etnis Simalungun. Pematangsiantar: Museum Simalungun.

[2] Bangun, R. 1989. Mengenal Orang Karo. Bandung: Cipta Karya

[3] Bangun, T. 1986. Manusia Batak Karo. Jakarta: PT. Inti Idayu Pers.

[4] Bogdan, R \& Biklen, S.K. (2007). Qualitative Research for Education: An Introduction to Theories and Methods, 5th Edition : Pearson

[5] Gustafson, K.L. 1981. Survey of Instrucyional Development Models. Syracuse, NY: Eric IR Document.
[6] Hutagalung, W. M. 1991. Pustaha Batak; Tarombo dohot Turiturian ni Bangso Batak. Penerbit Tulus Jaya.

[7] Joyce, B. R. (1991). Models of teaching. Fourth Edition. Boston-London- Toronto- SydneySingapore: Allyn and Bacon Pulishers.

[8] Nadler, L. 1988. Designing Training Program.Massachussetts : Addison-Wesley Publishing Company.

[9] Nasution, F ., \& Sembiring, A. 2007. Budaya Melayu, Medan : Badan Perpustakaan dan Arsip Daerah Prov.Sumatera Utara.

[10] Prinst, D. 1986. Sejarah Dan Kebudayaan Karo. Bandung: Yirama.

[11]Purba, D. K dan J. D. Poerba. 1995. Sejarah Simalungun. Jakarta: Bina Media

[12] Purba, M. D. 1977. Mengenal Kepribadian Asli Rakyat Simalungun. Medan: M. D. Purba.

[13]Purba, M.D. 1985. Adat Perkawinan Simalungun. Medan : M.D Purba

[14]Putro, B. 1981. KaroDari Jaman Ke Jaman I. Medan: Yayasan Massa

[15] Sembiring, A., Nasution, F., \& Nasution, B.A. 2010. Bahasa Melayu, Bandung: PT. Indahjaya Adipratama.

[16] Simanjuntak, B.A.S. 2006. Struktur sosial dan sistem politik Batak Toba hingga 1945: Suatu pendekatan sejarah antropologi budaya dan politik. Jakarta: Yayasan Pustaka Obor.

[17] Simanjuntak, S. 2015. Foklor Batak Toba. Jakarta: Yayasan Pustaka Obor.

[18] Simorangkir, M.S.E., Nainggolan, T., Pasaribu, J.B., \& Simanjuntak, B.A (ed.). 2015, Karakter Batak: Masa lalu, Kini dan Masa Depan. Jakarta: Yayasan Pustaka Obor.

[19] Singarimbun, Masri. 1993. Karo Siadi. Medan: Inti Ida Yupres

[20] Sitepu, Sempa. 2013. Sejarah Pijer Podi Adat Nggeluh Suku Karo. Jakarta: Delta Pamungkas

[21] Sumbayak, J. 2001. Refleksi Habonaron Do Bona Dalam Adat Budaya Simalungun. Pematang Siantar: Komite Penerbit Buku-Buku Simalungun (KPBS).

[22] Tambun, P. 1952. Adat Istidat Karo. Djakarta: Balai Pustaka.

[23] Yakup dan Umar Hadi. 2010. Adat dan Adab Melayu, Bandung: PT. Indahjaya Adipratama. 